\title{
Article
}

\section{Transformational Sexualities: Motivations of women who pay for sexual services}

\author{
Kingston, Sarah, Hammond, Natalie and Redman, Scarlett \\ Available at http://clok.uclan.ac.uk/31304/ \\ Kingston, Sarah ORCID: 0000-0002-9226-1915, Hammond, Natalie and \\ Redman, Scarlett (2021) Transformational Sexualities: Motivations of women \\ who pay for sexual services. Sexualities, 24 (4). pp. 527-548. ISSN 1363-4607
}

It is advisable to refer to the publisher's version if you intend to cite from the work. http://dx.doi.org/10.1177/1363460720904646

For more information about UCLan's research in this area go to

http://www.uclan.ac.uk/researchgroups/ and search for <name of research Group>.

For information about Research generally at UCLan please go to http://www.uclan.ac.uk/research/

All outputs in CLoK are protected by Intellectual Property Rights law, including Copyright law. Copyright, IPR and Moral Rights for the works on this site are retained by the individual authors and/or other copyright owners. Terms and conditions for use of this material are defined in the policies page.

\section{CLoK}

Central Lancashire online Knowledge www.clok.uclan.ac.uk

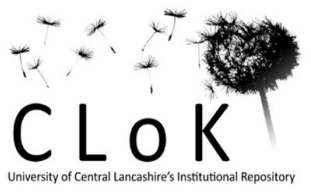




\title{
Transformational Sexualities: Motivations of women who pay for sexual services
}

\begin{abstract}
Previous research on client motivations to purchase sexual services in the UK has predominantly focused on the experiences of men. Women who buy sex have largely been overlooked, as it is commonly assumed that women provide, rather than purchase sexual services. In addressing this empirical absence, this article examines data gained from 50 interviews with women clients and sex workers. It examines the reasons why women decide to purchase sexual services in the UK. We argue that the increasing importance of contemporary capitalism and consumerism has shaped women's engagement in the sex industry as clients. We show how women's sexual agency and assertiveness as clients, inverts the female sex worker/male client binary assumed to characterize commercial sex and illustrates the overlap and convergence of male and female sexuality. Our research thus contributes to an understanding of female sexuality more broadly, as exemplifying the hallmarks of 'transformational sexualities' in cosmopolitanism (Plummer, 2015).
\end{abstract}

Key words: women who buy sex, prostitution, sex work, motivations, female sexuality 


\section{Introduction}

Despite an abundance of research on the sex industry internationally, the predominant focus has been on women who sell sex. Research on male or trans sex working and men clients has received less attention. Although there has been a historical absence of research on male clients, there is now a developing body of scholarship that seeks to explore men who pay for sex (Earl and Sharp, 2007; _ _ _ Logan, 2010; Sanders, 2008a, 2008b). Literature on women clients both in the UK and globally is not as developed and much less is known about women as clients. Much research on women clients comes from international studies that explores women who pay for sex through the lens of 'female sex tourism'. This has captured the experiences of women who travel to engage in sexual relations with local men in countries such as Barbados, the Dominican Republic, Costa Rica, as well as in Kenya, Italy, Greece and Spain (De Albuquerque, 1998; Frohlick, 2008: Herold et al, 2001: Kibicho, 2016: O’Connell-Davidson \& Sanchez-Taylor, 1999; Phillips, 2008; Sanchez-Taylor, 2001). This is sometimes referred to as 'romance tourism' because payment of sexual services is rarely direct and instead consists of days out, hotel rooms and meals (Pruitt and Lafont, 1995). Women's engagement in sex tourism is constructed through a discourse of romance and longterm relationships and thus set apart from men's sex tourism. As such, the experiences of women who pay for sex in a direct manner i.e. through direct monetary payment for specific prearranged sexual services, has yet to be examined in any depth in the UK.

International research has begun to capture the existence of women who pay for sex in a direct manner. For example, Frohlick (2008:143) identified how she had 'heard of women who arrive with cash in hand to pay willingly for sex with a local man' in Costa Rica, yet she did not interview such women. Likewise, although Phillips (2008:203, our emphasis) notes that 'liaisons' between European women and 'Beach boys' 'may start off simply as "sex for money"', she did not however document examples of such transactions within her case 
studies. Furthermore, whilst research on lap dancing in the USA has identified men strippers who have been offered payment for sex from women (Dressel and Peterson, 1982), an examination of the experiences, motivations or characteristics of women who buy sex in the UK has, to our knowledge, been lacking.

In addressing this limited knowledge base, this paper examines the reasons why women choose to pay for sexual services in the UK, from a client and sex worker perspective. This research adds to a developing body of literature on women clients as well as confronting often-held views of women involved in sex work as exploited victims. Rather, our original data offers new insights into women's involvement in the sex industry by demonstrating that women clients decide to purchase sexual services for a range of reasons. Significantly, our research also shows that there are similarities between the literature on men's motivations for purchasing sex and the women clients involved in our study. That men and women pay for sexual services for similar reasons, challenges the claim that has been drawn on in UK policy and that has driven policy shifts towards the criminalisation of clients in countries such as Sweden, Iceland and Norway. Such claims argue that prostitution can only be understood as men's violence and exploitation of women. Instead, our empirical data on women's engagement as clients in the UK, demonstrates they are active agents in their own sexual encounters. This phenomenon can be understood by considering the social, historical and cultural context in which these women are situated in the UK, as their experiences embody signs of contemporary capitalism and consumerism. Our research thus contributes to an understanding of female sexuality more broadly, as exemplifying the hallmarks of 'transformational sexualities' in cosmopolitanism (Plummer, 2015). 


\section{Research on the purchasers of commercial sex}

Previous research on the purchasers of commercial sex has predominantly examined the experiences of men clients, and to lesser extent women sex tourists. This body of research has identified that there are a range of reasons why men pay for sex. These reasons include emotional intimacy and the desire to pay for more than just sexual physical contact (Earle and Sharpe, 2008; Sanders, 2008a). For some men this stemmed from feeling that their marriage was emotionally and/or physically unfulfilling (McLeod, 1982; Sanders, 2008a), because they felt lonely (Jordan, 1997) or because they were unable to form 'conventional' sexual relationships (Campbell, 1998 Xantidis, \& McCabe, 2000). The ability to engage in physical sexual contact with a variety of sexual partners for specific characteristics such as age or ethnicity, has also been identified as a reason why some men pay for sex. As well as the opportunity to engage with a variety of partners without maintaining a series of complex affairs (Campbell 1998; Campbell 1997; Huschke and Schubotz, 2016; McKeganey and Barnard 1996; Pitts et al, 2004; Sanders, 2008a; Vanwesenbeeck, et al. 1993). The ability to pay for specific sexual services such as oral or anal sex was a motivation for others (Pickering et al, 1992; Kinnell, 1989; Monto, 2000). Likewise, the pursuit of excitement, thrill and fun through engaging in an illicit act was an appeal for some men and the resistance to normative hegemonic models of sexual practices (Campbell 1998; Campbell 1997; Kong, 2015; McKeganey and Barnard 1996; Monto 2000). In contrast to some of these motivations in which men's involvement could be seen as supporting traditional views of masculinity, men's desire for the emotional intimacy that sexual contact can bring, is a feature of more contemporary sex work research (see Birch et al., 2017; Milrod and Weitzer, 2012; Sanders, 2008a).

Paying for sex tends not however, to reflect one motivational factor. The recognition that paying for sex involves more than just sexual relief as highlighted above, has led to the 
development of typologies of motivations. Pitts et al. (2004) identified three broad motivations: factors of ease (avoidance of relationship, desire for specific sexual acts, less trouble than conventional relationships); engagement (desire for company and emotional engagement of the sex worker); and arousal (desire for relief and negative association with drugs or alcohol). Sanders (2008a) lists four motivational factors: emotional need (loneliness or lack of intimacy), life course stage (older men becoming widowed), unsatisfactory sexual relationships (deterioration of sexual or emotional aspect in non-commercial relationships), and difficulties with non-commercial dating (disdain for casual sex). These 'push' factors “aspects of men's lives that are lacking" are contrasted to 'pull' factors - aspects of the sex industry that are attractive and are promoted as "entertainment" (Sanders, 2008a: 40). 'Pull' factors refer to the more cultural aspects of the sex industry, its "nature ... what it offers and the glitzy ... images and promises that emanate from adverts, websites, stereotypes, pictures and the allurement of fantasy created specifically for those who want to trade cash for pleasure" (Sanders, 2008a: 45). This appeal, coupled with the expansion, mainstreaming and diversification of the sex industry, has occurred alongside Bernstein's (2007a) recognition of a shift from relational to recreational models of sexual behaviour. The acknowledgment of commercial sex as a legitimate form of entertainment, from entertaining business clients (Allison, 1994) to sex tours abroad to visit a 'different reality' (Martilla, 2008: 39), coupled with the increased corporate organisational structuring of various sex industry markets (Brents and Hausbeck, 2007), assist these shifts. This desire to visit alternative realities allows clients to escape from the mundane practices and process of daily life 'leaving behind their values, morals, expectations and responsibilities as a husband, a father, or a worker and being able to be "purely selfish"” (Martilla, 2008: 39). However, these shifts have not been fully acknowledged in some debates, and wider changes to sexual life, including the opportunities for women to engage sexually have certainly been less considered. 
Literature on female sex tourism has documented the reasons why some women travel to exotic locations such as Asia, the Caribbean and Europe to engage in sexual relations with local men. This body of knowledge has sought to explain the phenomenon by examining the colonial history of the Caribbean (Sanchez-Taylor, 2001), the hypersexualisation of ethnic 'others' (Pruitt \& LaFont, 1995) as an attempt to 'consolidate or redeem their own cultural identities' (Kempadoo, 2001:57), ethnic and economic privilege (Jeffreys, 2003; Opperman, 1999) 'to improve or consolidate their position on status hierarchies of gender, race and sexuality.' (Sanchez-Taylor, 2006: 52) as well as exercise their power and 'control over the management of self and others as sexual, racialized and engendered beings.' (O'ConnellDavidson and Sanchez-Taylor, 1999:37). This sparse body of literature has identified that women often seek courtship and romantic relationships but whether knowingly or not pay for companionship through paying for meals, accommodation, and gifts (O'Connell-Davidson, 1999; Opperman, 1999; Sanchez-Taylor, 2001, 2006). As a result, Pruitt and LaFont (1995:423) argue that this phenomenon could be more appropriately termed 'romance tourism' because 'these liaisons are constructed through a discourse of romance and longterm relationships, an emotional involvement usually not present in sex tourism'. Although as Sanchez-Taylor (2001) has argued, local men in the Caribbean did engage in explicit cash exchanges for sexual relations with women and couples, overall for women the economic transaction was less formally arranged. Instead, these women would often believe they were helping financially rather than paying for a sexual service.

More recently, the work of Pilcher (2011 and 2016), Neville (2018) and Sanders-McDonagh (2010, 2015 and 2016) add nuance to the study of women as consumers of commercial sexual experiences. Whilst Pilcher explores the female gaze in the context of venues (erotic dance clubs) Sanders-McDonagh compares red light areas within the Netherlands and Thailand to 
highlight how women are actively interested in (and pursuing) sexual entertainment in areas that might typically be seen as spaces for men and thus querying women's access to, and experiences of, sexual spaces. Neville, meanwhile, offers an in depth analysis of women who consume 'men on men' pornography, opening with 'being a human who is sexual - who is allowed to be sexual - appears to be a freedom more readily afforded by society to males than females' (2018:4). For women in Neville's research, the most commonly cited reason for enjoying $\mathrm{m} / \mathrm{m}$ pornography is the aesthetic of men having sex with other men - it is men's bodies, not women's that are the objects of sexual attraction (2018:35). These accounts serve as testament to a growing sphere of women who are active agents in pursuing commercial sexual entertainment. How, then, does this translate into a more direct consumption of embodied sexual services?

Whilst accounts of women offering to pay for sex in a more direct and explicit way has been noted in academic literature (Dressel and Peterson, 1982), the reasons why women purchase sexual services in the UK has yet to be explored in any depth. Our study seeks to address this gap and does so here by exploring the reasons why women pay for sexual services in the 'traditional' sense, i.e. the exchange of cash for sexual services.

\section{Methods}

Our study is based upon interviews with 10 women clients, 4 women who paid for commercial sex as well as sold it, and 34 sex workers (men, women and trans providers). The study aimed to examine the motivations and characteristics of women who purchase sex, who and where they buy sex from and to explore how physical and sexual safety are negotiated. Originally, we focused on women and sex workers living or working in the UK, but later interviewed two British women who lived and/or travelled and worked abroad, one 
sex worker from Canada and one from Australia, as they sometimes travelled and worked abroad. Participants were recruited by snowball sampling through our networks and contacts, and through promoting our study in the national press. Traditional spaces where sex is bought and sold in the UK such as indoor establishments and on-street 'beats' tend not to cater to women clients. Thus, we recognised that accessing women clients in the UK would be challenging and chose to include sexual service providers to help advance the knowledge base around women clients.

The study of sex work has become increasingly contentious, something the research team held in mind throughout the process and we endeavoured to research ethically and responsibly. All members of the research team had prior experience conducting research with sex workers and clients, alongside frontline service delivery to sex workers through local organisations. We recruited participants using a variety of means including; canvassing individual and agency websites; utilising social media platforms; 'opportunistic' recruitment; a press release; an email and postal campaign and finally, asking participants we interviewed if they had contacts they could share the project details with (see for further methodological details). Interviews were conducted face to face, over the phone, skype or by email. Interviews were transcribed verbatim and thematic analysis was used to analyse the data (see Braun and Clarke, 2006). Data was coded in the qualitative data analysis software tool Nvivo using a coding framework, from which we identified key themes and then organized them around global themes (Attride-Stirling, 2001). The global theme, 'motivations of women who buy sex' will be examined in this paper. Participants are referred to using a pseudonym as chosen by them.

\section{Demographic Characteristics}


The women clients we spoke to came from a range of social backgrounds and professions such as nursing, air-hostessing, accounting and teaching. They ranged in age from 30s-50s. Some were married with children, others were single with no children. In terms of the sex workers we spoke with, nine self-identified as women, 27 as men and two as trans women. Their ages ranged from 20s-50s and they had provided services to women clients and women in heterosexual and lesbian couples for, in some cases, over several decades.

\section{Findings}

Women clients and service providers identify several reasons why women decide to pay for sexual services in the UK. It is important to point out here that, although we discuss women buying sex, this is not in the conventional sense of paying for heterosexual penetration with a man. The sexual services spoken about and requested by women span a range of sexual activity including massage and foreplay, oral sex, BDSM activities and penetration. Some clients and providers identify that some women pay for sex for one or, more often, multiple reasons as the literature around men clients reviewed above supports. These motivations include the desire for no strings sex, experimentation and critical moments, sex about me, sex with a certain type of person, power and control, and intimacy.

\section{No Strings Sex}

Many women clients we spoke with paid for sexual services because they wanted physical sexual contact and/or intercourse and nothing more. Women clients did not want any emotional attachment, and instead sought no strings sex. For some women, they wanted sex either because their partner was not satisfying them sexually or because they were single and had neither the time nor energy for a committed relationship. In the words of Unsinkable Molly Brown: 
I'm a mum, I'm on my own, I'm a busy professional, I don't want a relationship ... I need an orgasm now and again, I need a bit of a sex fix which doesn't come from a sex toy ... to hit a spot then move on .... the next morning, get up and look after my little boy and not have to worry about "where are you and when are you free" and all that jazz. I think that would really be quite nice, it would fill a little bit of a gap in my life ... it would be a sex fix pure and simple. (Unsinkable Molly Brown, 30s, client)

As with literature on men who pay for sex (Sanders, 2008a), some women clients did not want the emotional commitment of a relationship and had busy professional lives, yet still wanted to have sexual pleasure.

In contrast, Arabella explained that whilst being happily married, her relationship lacked sexual satisfaction:

I'm married to older man and our love life is not amazing. Gave it lot of thought and wanted sex but without emotion and not an affair. Want to stay married.

(Arabella, 37, client)

Literature on men who buy sex has likewise identified that some men who paid for sexual services were happily married but did so because they felt that their sexual desires were not being fulfilled in the marriage (_ McKeganey \& Barnard, 1996; McLeod, 1982; Sanders, 2008a). Commercial sex offers women the opportunity to obtain sexual satisfaction, without threatening their current personal relationships. This parallels work around married men who when faced with relationship challenges pertaining to sex do not see breaking the relationship as a viable option (Mooney-Somers and Ussher, 2010) and seek out 
commercial sex instead. The narratives from clients and sex workers were clearly threaded with the notion that either women clients did not want to leave their partners or that paid-for was preferable over other types of sexual encounters. Thus Bernstein's (2007b) bounded intimacy, in which men have access to uncomplicated sexual encounters in conjunction with long term domestic relationships, enabling commercial sex to exist side by side with noncommercial relationships, and not in opposition to them, can also be applied to women who pay for sex.

Service providers echoed that some women who booked them were motivated by a desire for sex either because they were too busy for a relationship, or were married and not sexually satisfied:

For some women it is because they've told me the only reason they see me is because their husband has a problem, or some of them they just say they're not interested, they're so busy with work and the whole, especially a lot of the English women, particularly, it's the culture of he goes to the pub and watches football. That kind of mentality, so they've tried to get it off their husband but it's not there (Arron, 30, provider/m)

The desire for no strings sex situates sex in essentialist models of sexuality, as a drive and as a powerful, uncontrollable force, notions that are typically associated with the male sex drive in the West (Allen, 2003; Hollway, 1984; Weeks, 2003). Women's motivation to pay for sex and nothing more, challenges essentialist notions of female sexuality that proscribe women's sexuality as passive and subordinate to men's (Jackson \& Scott, 2010). Instead, women clients we spoke with demonstrate their sexual agency, highlighting progressions in female sexuality and women as active sexual consumers. 
Age was another factor used to explain why some women were motivated to purchase sex. Some service providers claimed that younger women were more likely to want physical sexual pleasure than older women:

The younger women, they just want sex, just literally the physical aspect of it ...

I've had it once or twice where with the young women, their word is just, fuck me. (Arron, 30, provider/m)

Generational differences in women's sex drive and sexual consumption has previously been documented in academic research. Research in the USA has shown that younger women are more likely to access pornography than older women (Price et al 2016). In a national UKbased survey about sexual behaviours, younger women were more likely to have multiple sexual partners than older women (Mercer et al., 2013). Furthermore, according to DeLamater and Sill (2005) as a woman ages her sexual desire decreases. Yet interestingly, women who purchase sexual services tend to be in their 30s and 40s according to sex workers; with fewer younger women clients. Perhaps women under 30 are less likely to have the economic capital required to purchase sex, or perhaps the expectation that younger women can procure sex readily without paying for it is a factor? Such questions raise further issues in need of exploration.

\section{Bounded Experimentation}

The ability to experiment and engage in new experiences was a key reason why some women (and women in couples) paid for sexual services. Some single women, as Max (30s, provider/m) claimed, were 'just out for something different', whilst others were in a couple 
Submission to Sexualities - Special Edition

seeking to 'try it out for the first time' (Michelle, 30s, client and provider/w), and experiment with their partners. There is very limited literature that explores anyone paying for sex as part of a couple, yet this was a key theme:

In most cases it's been part of a couple ... When couples tend to come, it tends to be a one off "let's go and try something new and interesting thing for our sex life". (Rebecca, 33, client and provider/transw)

A lot of the women have been with their partners for a long time and they want to, they feel comfortable enough to experiment. (Chris, 50s, provider/m)

For some couples the woman partner wanted to experiment sexually with another woman: 'You get women in couples who want the three-way with the lady' (Margaret, 35, provider/w); 'Most of the women would be a husband and wife for a threesome ... female on female sex would be what they want.' (Christy, 50s, provider/w). For other women, 'her fantasy was that she would be watched having sex by her boyfriend.' (James, 40s, provider/m).

Whilst experimentation was a driving factor, this often intersected with a desire to create a bounded encounter that would not pose a threat to the relationship, or to their reputation:

they're not out and out lesbians, so it might be something they want to try for the first time or something they want to keep secret or private, they don't want to be seen... they may be married, they're supposed to be straight (Michelle, 30s, client and retired provider/w) 
they ... wouldn't want to do the same thing with the same person too regularly ... to [stop] either of them getting fond of the person ... keep it compartmentalised and emotionally distanced ... for their relationship. (Rebecca, 33, client and provider/transw)

it's easier to pay for it because then if they tried it with someone else, a friend or something, it can go wrong then can't it. One person can get jealous (Samantha, 37, provider/w)

As with literature on men clients, the ability to be discreet and hide their sexual activities away from others was a key factor (Pruitt \& Krull, 2010). Paid-for sex provided couples with a discreet and bounded opportunity to experiment with their sexuality. As Bernstein (2007b) argues commercial sex offers men clients the opportunity for bounded authenticity where the "recreational sexual ethics derives its primary meaning from the depth of physical sensation and from emotionally bounded erotic exchange" (2007: 6). In this situation, paying for sex enables couples to engage in recreational sex with another person whilst also protecting the emotional aspect of their partnership. From these accounts it is clear that cultural expectations around monogamy and heteronormativity have informed their decisions to pay for sexual services. The need to compartmentalise, create clear boundaries and conceal their activities shows that their paid-for sexual encounters challenge dominant ideals around marriage, relationships and heterosexuality. Paid-for sex enables them to manage the potential stigma and repercussions of their sexual experimentation. Indeed, 'to be publicly known as bisexual and non-monogamous tends to have particularly stigmatizing effects on women.' (Klesse, 2005: 445). A paid-for encounter can be a convenient solution. 
Yet whilst women clients are aware of these societal expectations, they choose to transgress these social and sexual boundaries, albeit temporarily as they continue to conform publicly. As with media portrayals of heteroflexibility, women clients' engagement with other women or men is cast as an "'add on" to otherwise conventional heterosexuality' (Diamond, 2005). ${ }^{1}$ Goffman (1971) explains how actors perform different performances in front of different audiences in front and back stage regions. In the front stage (home or working life), some behaviours may be frowned upon, or threatening for women, such as performing a sexual identity where one engages multiple partners. In the back stage (commercial sex), however, there is no need to mask this aspect of their identity and women are able to engage in impression management, outwardly being seen as heterosexual and monogamous, but behind closed doors experimenting sexually with other men or women.

\section{Critical Moments}

Women clients also identified how they began to experiment and seek new experiences at 'critical moments' in their lives:

I think it started with an idea when I began being more experimental about 37, 38 (5 or 6 years ago), so I contacted an escort ... I read about these sensual massages with a happy ending for women by men and decided to treat myself to one. (Misty Robinson, 45 , client)

I have got a new job and new location so I feel off kilter with things ... I am spending more money on myself! (Liz, 42, client)

\footnotetext{
${ }^{1}$ Heteroflexibility has been used to describe women who self-identify as heterosexual, but sexually explore and experiment sexually with other women (Diamond, 2005; Frohard-Dourlent, 2012).
} 
Generational changes in terms of parenting, employment patterns, relationship status and economic stability were some of the key factors that informed participants' desire to pay for sexual services. For some women, these moments became a catalyst for sexual change. Previous research on divorce has shown that American women's sex lives become less inhibited and more intense after divorce (Goetting, 1981). Negative experiences across the life course have also been said to affect sexual behaviours (Kessler \& McLeod, 1984). As we have explored above, critical moments identified by our participants, for some, relate to changes across the life course. For women who pay for sexual services this tends to take place in the 30s and 40s, the age of the majority of women clients we interviewed, and reported by service providers. Interestingly, when we examine average salaries in the UK across the life course, women's earnings peak in their 30s, and decline very slightly in their 40s (Office for National Statistics, 2018). Furthermore, the average age of marriage for women in the UK is in their early 30s, yet those in their 30s and 40s had the highest rates of divorce between 2000 - 2013, for periods of less than a year up until 14 years of marriage (Office for National Statistics, 2015). In addition, according to the average age of mothers in the UK since the 1960s, those in their 30s and 40s at the time of our research, were likely to have had children of high school age or adults (Office for National Statistics, 2017). There appears therefore to be particular cohort effects for women in their 30s and 40s, where economic ability, available time, opportunity and sexual desire intersect to inform women's decisions to pay for sexual services. As we examine below, these intersections are also shaped by the social context in which these women are situated. 
Submission to Sexualities - Special Edition

\section{Sex about me}

Some women clients decided to pay for sexual services because the encounter would focus solely on their sexual needs: 'The most common one, especially among my regulars, is the simplest - they enjoy an experience that's all about them.' (Dan, 31, provider/m); 'my motivation is, I find it quite a turn on ... it's the idea of somebody is there to pleasure me' (Michelle, 30s client and provider/w). This parallels findings from work around men who pay for sex in that some men purchase sex so the sexual experience is focused on them rather than their partner (Campbell 1998; Monto 2000).

Yet some scholars have argued that the belief in self-determination of sexuality and sexual pleasure reflects false consciousness. Indeed, as Rich has argued in the context of heterosexuality, heterosexual women often believe that they freely choose to have sex with men, but instead are conditioned to do so. Thus, the 'sex' that women believe they want and pay for may be a reflection of proscribed sexual preferences and desires, rather than their own intrinsic appetites. However, this belittles women's agency and does not account for women who experiment sexually with other women. Nor does it account for the women in our sample who paid for what would be typically seen as a 'selfish' experience, for example, massages with 'happy endings'. There are others who claim that contemporary society promotes individualism, self-determination and agency (Bauman, 2000; Weeks, 2007). As Attwood (2005) argues in the context of the marketing of sex to women in contemporary society, there is a much greater focus on female autoeroticism and less attention to the male gaze. Women are instead engaging in 'hedonistic indulgence, of consumerism, sexual display and self-fashioning.' (Attwood, 2005, p. 400). Women clients' motivation to pay for sex because it satisfies their sexual desires is further evidence of what Attwood (2005) calls the 'making over of sex'. 
This discourse was also found amongst women clients who were also sex workers; the focus on satisfying their sexual appetite was a motivating factor: 'female escorts are obviously having sex often, the sex they are having is usually always about pleasing and satisfying the client ... on a few occasions they have booked me so the focus is on pleasing them.' (Matthew, 33, provider/m); 'it was a turn on or satisfying for somebody to do something sexual to me' (Rebecca, 33, client and provider/transw). This represents a challenge to traditional gender role ideology that underpins ideas about commercial sex, the power dynamics between men and women, and women's assumed passivity in the UK sex industry. Research on role reversal and woman breadwinners in the USA has shown that for some women, being the breadwinner signifies their empowerment and self-fulfilment (Medved, 2016). Whilst it has been claimed that sex workers often feel empowered by their work (Jones, 2016), claims that this is disillusioned and that there are many examples of disempowerment (Jeffreys, 2009), continue to divide debate in relation to the power dynamics between women sex workers and men clients. By women sex workers purchasing commercial sex from men or women (both cis and trans), they trouble claims that the sex worker/client power dynamics are based solely upon gender. If, as it has been claimed, the vast majority of sex workers are women due to gender inequality and men's motivation to dominate women (Rahman \& Jackson, 2010), are women paying for sexual services because relations between men and women are more equal and because they want to dominate men? Domination of men was not explicitly identified by women clients we spoke with, and some women pay for sexual services from other women and trans women. However, many did state that they wanted to pay for specific types of sexual services from men, arguably commanding power over men's bodies, and from men who had particular physical characteristics. 


\section{Sex with a certain type of person}

Commercial sex provided women clients with the opportunity to utilise their economic power to gain sexual access to persons they may not normally be able to have sexual relations with outside of commercial sex. Women used their monetary position to seek out and have sexual contact with persons who had specific physical characteristics and features. These related to the age of the service provider, their hair colour, ethnicity, height, and body type. For example, Annie explained the type of man service provider that she would choose to purchase services from

I figured that if I was going to cheat on my husband by having sex with someone else I was going to do it with someone really good looking, younger than me (I am in my 40s) and who was presumably an expert.... tall, athletic, dark hair, in their 30s. (Annie, 45, client)

Purchasing sex from someone who was a particular 'type' of person was also identified by Arabella (37, client) who stated that the service provider 'looked my type really. Right age, etc', by Liz (42, client) who identified her type as 'Mediterranean gods' and by Michelle who explained the type of woman she is attracted to: 'Well, I guess I have a type. I like the blonde girls and I like massive boobs and I like curvy women ... good arse and big tits' (Michelle, 30s, client and provider/w).

Literature on men clients has also documented how some men purchase sexual services because they seek sexual relations with women with certain physical characteristics such as large breasts, women of a particular ethnic background, slender or curvaceous women (McKeganey and Barnard 1996; Pitts et al, 2004; Sanders, 2008a; Weitzer, 2009). Likewise, literature on female sex tourism has identified how some women travel to specific locations 
to engage in sexual or romantic relationships with local men, seeking them out for their ethnic characteristics (Sanchez-Taylor, 2001, 2006). As Sanchez-Taylor (2006:52) has argued, women sex tourists take advantage of their economic and racial privilege to 'obtain a sexual advantage that would otherwise have been denied to them'. The women in our research likewise identified that commercial sex enabled them to purchase sexual services from a person they would ordinarily not have sexual access to.

\section{Power and Control}

The ability to stipulate and control the sexual service experience with men service providers was a driving factor for some women in our research. Their economic power enabled them to exploit the commercial sexual relations available to them and command a degree of control over another person's body, ensuring their sexual desires were central:

There is the aspect of control .... I was able to tell him what I liked and didn't like and he would totally listen to this and respond accordingly" (Liz, 42, client)

The advantage is that I can dictate the style and content of the sex as I am paying the bill in effect. (Arabella, 37, client)

It was something I fantasied about, being in control to do and get what I wanted because it was up to me ... I could control and choose to do it in a professional way ... I felt it empowered me. (Misty Robinson, 45, client)

That these women seek to purchase sexual services to command more control over the sexual encounter, suggests that they command less or equal power in more conventional sexual relationships. Previous scholarship on heterosexuality has suggested women are deemed more passive and men more aggressive in sexual relationships (Rahman \& Jackson, 2010). 
Sexuality is often seen as a focal site of male heterosexual power (Sanchez-Taylor, 2001). Men are believed to reaffirm their power and masculinity through penetration of women's body and women submit to male desires (Dworkin, 1987). Women's purchase of sex from men may represent an inversion of that power and demonstrates transgressions in sexuality from traditional notions of femininity, albeit temporarily constrained to commercial sex. Indeed, some women who paid for sex identified that they felt empowered by commercial sex. Clearly, men and women are not undifferentiated groups where one holds all the power all the time. To theorise all sexual relations between men and women on this basis, reproduces essentialist notions of sexuality. Rather, we argue that in commercial sex we see evidence of male and female sexualities converging

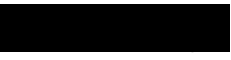

\section{Intimacy and Companionship}

Some women clients paid for the services of a sex worker for more than just sex. Some sought 'intimacy', commonly associated with conventional relationships. As Michelle (30s, client and provider/w) explained:

I just like to have that feeling of intimacy... missing that intimacy you get when you're in a relationship ... if you can take that for an hour or so ... that's enough. Honestly, I'm single now and I've no intention of getting into a relationship...sometimes you just feel lonely ... it's better than nothing I suppose.

Intimacy is identified in literature on men client's motivations (Jordan 1997; Pickering, et al. 1992; Vanwesenbeeck, et al. 1993). For some men the lack of a conventional relationship and feelings of loneliness, a lack of self-confidence or because they perceive themselves to be unattractive, have been identified as their motivation for purchasing sexual services (Birch et 
al., 2017; Campbell, 1998; Jordan, 1997; Xantidis and McCabe, 2000). For others, the lack of emotional intimacy in their conventional long-term relationship has led them to engage in the industry (McLeod, 1982; Sanders 2008b). With men and women clients, the desire for 'bounded authenticity' (Bernstein 2007b), where intimacy is limited yet convincing, is evidently a motivation factor (see Milrod and Weitzer, 2012). Whilst it is commonly assumed that it is women who seek emotional intimacy from sexual relations, the commonality between men and women's motivation to purchase bounded intimacy again confronts essentialist approaches to sexuality that assume men and women are distinct in their approaches to sex.

According to Bernstein, men clients' desire for 'bounded authenticity' is best illustrated by the 'girlfriend experience' some men seek. The GFE can include going out for meals, or it could include a session with a sex worker that is more intimate with kissing and cuddling (Huff, 2011; Milrod and Weitzer, 2012). As with research on men clients, our findings demonstrate that women clients seek the 'Boyfriend/Girlfriend Experience'. Women clients and service providers stated that this is a type of service many lone women clients seek; 'I said I wanted kissing [and the] full BF experience' (Arabella, 37, client). The boyfriend/girlfriend experience was described as an experience that was similar to dating, whereby client and service provider would, for example, go out for a meal, go to the cinema, or an 'evening out at a concert' (Edward, provider/m), and may or may not engage in physical sexual contact afterwards:

Women are looking for more of the old-fashioned escorting type of date as in the company for the evening and someone to talk to. (Max, 30s, provider/m) 
being a partner at an event, where it's awkward for a lady to attend on her own. I've been to work dos ... ballet or theatre or classical music concerts, concerts (George, 59, provider/m)

I often get to go to the theatre, or ballet, or a concert, just to accompany them ... I have one ... for dinner date only, to just go to a restaurant and have something to eat and it's never been anything more than that .... there may be some circumstances where it's not practical to finish it off with sex or the lady in question just doesn't want it ... I guess it's something like $75,85 \%$, some kind of sexual activity will always be involved. (Edward, provider/m)

Our data suggests that some women hire an escort for companionship only, and whilst some degree of intimacy is involved, direct sexual contact is not always required. The lack of data around paid companionship, which does not necessitate a sexual interaction, highlights a research gap. As we explore below, the increasingly detached, remote and individualised nature of contemporary western societies may help explain why some women clients are seeking bounded intimacy.

\section{Discussion}

Women's position in the social, economic and sexual sphere has undergone significant shifts 'transforming' women's sexual behaviour in tandem with a cultural context that promotes and encourages women's sexual desire. The last 50 years has seen significant social changes influencing sexual and intimate attitudes and behaviours including: the shift in women's position within labour markets; alternative educational opportunities and reproductive choices; secularisation, which has undermined traditional religious norms relating to divorce, 
cohabitation and homosexuality; the separation of sex from reproduction and marriage; the separation of marriage from parenting; and some questioning of gender fixity and normal/ abnormal boundaries (Scott, 1998; Weeks, 2009). The 'sexual revolution', the changes in sexual attitudes and sexual liberalisation occurring since the 1960s (Kraaykamp, 2002), brought a new model of intimate life based on democratic, hedonistic individualism, which was more tolerant, experimental and accepting of diversity and choice than before (Weeks, 2009: 20). Scott (1998) argues that in Britain, between the early ' 80 s and '90s, there were shifts in women's attitudes to pre-marital sex and homosexuality, deeming them more acceptable, and more aligned with men's views on premarital sex.

These shifts can be explained through Hawkes' (1996) four aspects of the liberalization of heterosexuality in which, the contraceptive pill (among other complex processes) uncoupled sex from marriage and procreation, desire became commercialized and choice emphasized, women challenged masculine models of sexual pleasure, and heterosexuality was no longer trapped within the constraints of marriage and lifetime monogamy. Giddens (1992) describes these changes as the outcome of 'plastic sexuality', understood as a "decentred sexuality, free from the needs of reproduction" (1992:2). However, an increase in freedom presents opportunities for a greater number of sexually intimate relationships, leading to a decline in the number of 'traditional' long-term relationships based on commitment. Love, care, understanding and empathy are less attainable when long-term marriage-type relationships are under threat, and selfish relationships are chosen instead (Jamieson, 1998). Because of a hard work ethic, women are juggling work and home life and only have time for semi-detached relationships (Bauman, 2003).

The changing nature of contemporary society in the West and the increasing focus on individualised sexual practices has therefore led to profound changes in the sexual landscape. 
Transformational sexualities are developing under modernity and link to the rise of capitalism and individualism, growth of new technologies and the media, and a decline in religion, amongst other changes (Plummer, 2015: 40-41). As Phipps (2014:10-11) claims in this context 'The drive to consume in order to both express and 'add value' to oneself is a key aspect of contemporary consumer culture ... The body is a key site at which this process occurs'. Therefore, it is hardly surprising that women are buying sex, as we have seen women's economic and social power increase; culture increasingly focuses on consumption and the body is one site of consumption (the body as a product of culture), and autoeroticism through sex toys. Our findings display the hallmarks of these transformational changes and help to broaden our understanding of female sexuality. In particular, we argue elsewhere that we may be witnessing 'converging sexualities', in that women are acting in ways that could be defined as masculine and feminine (Reference Removed). In this work, we draw upon sexual scripts theory and complexity theory to argue that sexual scripts are evolving in ways that blur the lines between what we understand as distinct male and female sexualities.

Historically women's sexual behaviour and desires have often been set apart and considered distinct to men's sexual behaviour; a finding not echoed here. According to Prasad (1999) the purchase of sex by men is deemed as natural behaviour for men and thus explaining it is unnecessary. In contrast, women's sexual behaviour has historically been considered passive and sexless. As Jolly et al (2013: ix) explains 'When it comes to women's bodies and sexualities, the focus too often is on disempowerment: on violence and violation, harm, risk and hazard. Even to speak of pleasure in the same breath as development causes a stir'. However, sex positive or sex-radical feminists during the 1980s sought to reposition sex as positive rather than problematic and dangerous (Queen and Comella, 2008). Nonetheless, too often, political discourses around female sexuality and sex work focus on the sexual danger, terrorism, exploitation, coercive power and domination women are subjected to 
(Kantola \& Squires, 2004). Whilst a body of literature has moved away from this and acknowledged sex worker agency, the overriding focus of research on women's experiences of the sex industry has been on the sale rather than purchase of sex.

Our study therefore supports counter-narratives to the dominant prevailing discourses around female sexuality. It problematizes the presumption that women are the sexual objects of heterosexual male desire, and that sex work involves the exploitation of women; a view commonly held by those who seek the abolition of commercial sex (see for example Jeffreys, 2009). We do not claim that sexual violence, exploitation and coercion does not exist. On the contrary, the violence and exploitation that sex workers face from a range of sources including the state, police, communities, partners, pimps, clients and those pretending to be clients is real, and occurs not due to the exchange of cash for sex, but due to the circumstances and regulation around such exchanges which make it harder for sex workers to operate safely (Kinnell, 2008). Rather, we seek to avoid reducing our analysis 'to the production of grand, universalizing notions about prostitution as the quintessence of women's oppression that rests upon the assumption of a unified category of 'woman.' (Kempadoo, 2001:57).

Instead, our research challenges the dominant interpretive schema for understanding women's sexuality and engagement in the sex industry. Our data destabilises the notion of women as passive service providers within the sex industry. Women clients are exercising their sexual agency in very specific, confident and assertive ways. Previous research on female sex tourism has documented how women exercise their economic power in developing countries, yet this example has been considered unique and culturally specific, as 'females will not have experience of male prostitutes in the West to make a comparison. There is no prostitution market for women.' (Jeffreys, 2003:231). Whilst we agree that women sex workers selling to men clients make up the largest proportion of the industry, 
according to current evidence, our data demonstrates that other, albeit smaller segments of the growing global sex work market exist. We can now say that we have men and women sex workers (both cis and trans) selling to women in a variety of different circumstances in the UK, both in couples and alone. Our research clearly demonstrates that there is a market for women sexual consumers in the UK.

\section{Conclusion}

The dominant trend in sex work research has been to examine the standpoint of women firstly as sex workers and to a much lesser extent as women sex tourists. To date, the experiences of women who pay for sex in a direct, explicit and prearranged manner has been sparse. Our research therefore makes an important contribution to the field of sex work research, by examining the experiences and motivations of women who explicitly, intentionally and directly pay for sexual services either on their own or in a couple in the UK. More specifically, these findings are significant in the context of the positioning of women in the UK sex industry. Our data shows how women exercise their economic privilege in commercial sexual transactions, as purchasers rather than providers of sexual services.

Yet our findings also offer new insights into female sexuality in the context of commercial sex in the UK. Our data challenges the assumption that women are always passive sexual objects of heterosexual men's desire in commercial sex. Instead, it demonstrates that the women sex worker/men client binary that has often characterised much research on sex work and permeates policy discourse and practice in the UK, masks the heterogeneous nature of commercial sex and essentializes men and women's sexual relations. Instead, women' sexual assertiveness and agency as consumers of paid-for sex in the UK, whilst for some may be an example of 'gender role transcendence' (Dressel and Peterson, 1982), for us illustrates the increasing confluence of male and female sexualities. We argue 
Submission to Sexualities - Special Edition

that our empirical findings can be understood in the context of contemporary capitalism and consumerism. As women's social and economic power has increased and sexually liberal ideals have proliferated, women can choose to purchase sexual services to satisfy their individual sexual desires. The transformation of female sexuality is observed in our findings, and displays the hallmarks of what Plummer (2015) terms 'transformational sexualities' in cosmopolitanism.

\section{References}

Allen L (2003) Girls want sex, boys want love: resisting dominant discourses of (hetero) sexuality. Sexualities, 6(2), 215-36.

Allison A (1994) Nightwork: Sexuality, Pleasure and Corporate Masculinity in a Tokyo Hostess Club. Chicago, Chicago University Press.

Attride-Stirling, J. (2001). Thematic networks: an analytic tool for qualitative research. Qualitative Research, 1(3), 385-405.

Attwood F (2005) Fashion and Passion: Marketing Sex to Women. Sexualities, 8(4), 392-406. Bauman Z (2000) Liquid Modernity. Cambridge: Polity Press.

Bauman Z (2003) Liquid Love: On the Frailty of Human Bonds, Cambridge: Polity Press. Bernstein E (2007a) Sex work for the middle classes, Sexualities 10(4): 473-488.

Bernstein E (2007b) Temporarily Yours: Intimacy, Authenticity, and the Commerce of Sex. London: The University of Chicago Press.

Birch, P., Baldry, E. and Hartley, V.H., (2017) Procuring sexual services: evidencing masculinity diversity and difference through sex work research. Sexuality \& Culture, 21(4), 1106-1119.

Braun, V. and Clarke, V., (2006) Using thematic analysis in psychology. Qualitative research in psychology, 3(2), 77-101. 
Submission to Sexualities - Special Edition

Brents BG and Hausbeck K (2007) Marketing sex: US legal brothels and late capitalist consumption, Sexualities 10(4): 425-439.

Campbell C (1998) Invisible men: Making visible male clients of female prostitutes in Merseyside. In Elias J, Bullough V, Elis V, Brewer G and Elders J (Eds.), Prostitution: On Whores, Hustlers and Johns. New York: Prometheus Books, pp. 155-171.

Campbell R (1997) 'It's just business, its' just sex': Male clients of female prostitutes in Merseyside. Journal of Contemporary Health, 5: 47-51.

De Albuquerque K (1998) In Search of the Big Bamboo. Transition, (77): 48-57.

DeLamater J D and Sill M (2005). Sexual desire in later life. The Journal of Sex Research, 42(2), 138-149.

Diamond L M (2005) 'I'm Straight, but I Kissed a Girl': The Trouble with American Media Representations of Female-Female Sexuality. Feminism \& Psychology, 15(1), 104-110.

Dressel P L and Petersen D M (1982) Becoming a Male Stripper: Recruitment, Socialization, and Ideological Development. Work and Occupations, 9(3), 387-406.

Dworkin A (1987). Intercourse. New York: Free Press.

Earle S and Sharp K (2008) Intimacy, pleasure and the men who pay for sex. In Letherby G, Williams K, Birch P, and Cain M (Eds.), Sex as Crime. Cullumpton: Willan Publishing, pp. 63-79.

Earle S and Sharp K (2007) Sex in Cyberspace: Men Who Pay for Sex. London: Routledge. Frohard-Dourlent H (2012) When the heterosexual script goes flexible: Public reactions to female heteroflexibility in the Buffy the Vampire Slayer comic books. Sexualities, 15(5-6), $718-738$

Frohlick S (2008) Fluid Exchanges: The Negotiation of Intimacy between Tourist Women and Local Men in a Transnational Town in Caribbean Costa Rica. City \& Society, 19(1), pp. $139-168$. 
Submission to Sexualities - Special Edition

Giddens A (1992) The Transformation of Intimacy: Sexuality, Love, and Eroticism in Modern Societies, Stanford: Stanford University Press.

Goetting A (1981) Divorce Outcome Research: Issues and Perspectives. Journal of Family Issues, 2(3), 350-378.

Goffman, E. (1971 [1959]) The Presentation of Self in Everyday Life. Edinburgh, Edinburgh University Press.
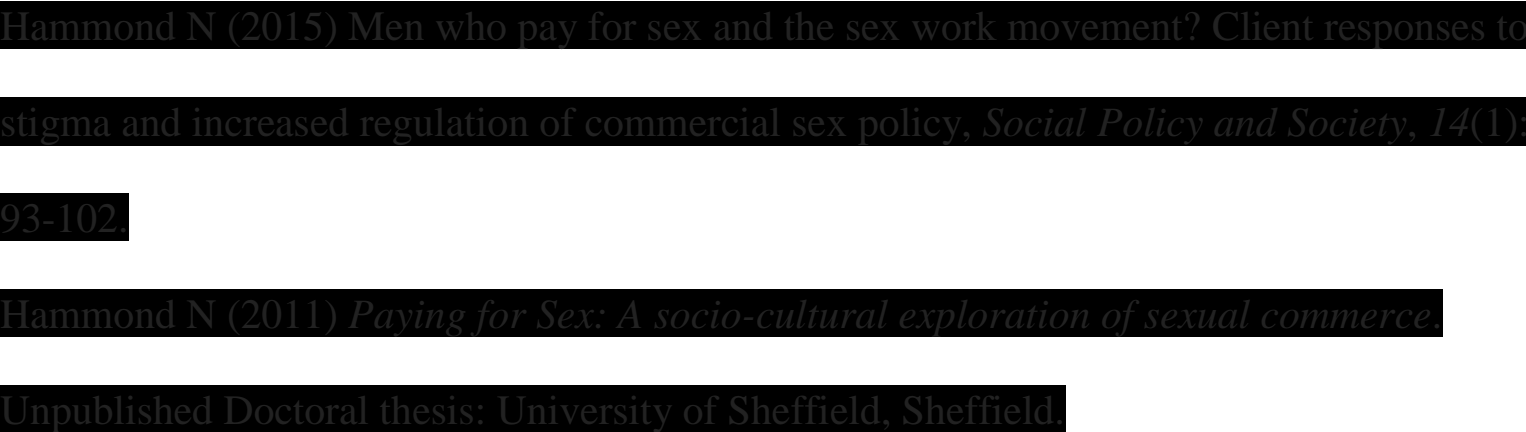

Hawkes G (1996) A Sociology of Sex and Sexuality. Buckingham, Open University Press.

Herold E, Garcia R, and DeMoya T (2001). Female tourists and beach boys: Romance or Sex Tourism? Annals of Tourism Research, 28(4): 978-997.

Hollway W (1984) Women's power in heterosexual sex, Women's Studies International Forum, 7(1), 63-8.

Huff, A., (2011). Buying the girlfriend experience: An exploration of the consumption experiences of male customers of escorts. Russell W. Belk, R., Grayson, K., Muñiz, A. and Jensen. H. Schau (Eds.) Research in Consumer Behavior (Volume 13) Emerald Group Publishing Limited, pp.111 - 126

Huschke, S. and Schubotz, D., (2016) Commercial sex, clients, and Christian morals: Paying for sex in Ireland. Sexualities, 19(7): 869-887.

Jackson, S and Scott S (2010) Theorizing Sexuality. Maidenhead: Open University Press. Jamieson L (1998) Intimacy: Personal Relationships in Modern Societies. Cambridge, Polity Press. 
Submission to Sexualities - Special Edition

Jeffreys S (2009) The Industrial Vagina: The Political Economy of the Global Sex Trade, London: Routledge.

Jeffreys, S. (2003). Sex tourism: do women do it too? Leisure Studies, 22(3), 223-238.

Jolly S, Cornwall A and Hawkins K (2013) Introduction: Women, sexuality and the political power of pleasure. In Jolly S, Cornwall A, and Hawkins K (Eds.), Women, Sexuality and the Political Power of Pleasure. London: Zed Books, pp. 1-27.

Jones, S. (2016). Sex Work and Female Self-Empowerment. New York: Routledge.

Jordan J (1997) User pays: Why men buy sex, Australian and New Zealand Journal of Criminology 30: 55-71.

Kantola J and Squires J (2004). Discourses surrounding prostitution policies in the UK. European Journal of Women's Studies, 11(1), 77 - 101.

Kempadoo, K., (2001) Freelancers, temporary wives, and beach-boys: Researching sex work in the Caribbean. Feminist Review, 67(1), 39-62.

Kessler R C \& McLeod J D (1984). Sex Differences in Vulnerability to Undesirable Life Events. American Sociological Review, 49(5), 620-631.

Klesse, C. (2005). Bisexual Women, Non-Monogamy and Differentialist Anti-Promiscuity Discourses. Sexualities, 8(4), 445-464.

Kibicho W (2009) Sex Tourism in Africa: Kenya's Booming, Aldershot: Ashgate.

Kinnell H (2008) Violence and Sex Work in Britain, Cullumpton: Willan Publishing. Kinnell H (1989) Prostitutes, Their Clients and Risks of HIV Infection in Birmingham, Department of Public Health Medicine: Central Birmingham Health Authority. Kong, T.S., (2015) Buying sex as edgework: Hong Kong male clients in commercial sex. British Journal of Criminology, 56(1), 105-122. 
Submission to Sexualities - Special Edition

Kraaykamp G (2002) Trends and countertrends in sexual permissiveness: Three decades of attitude change in the Netherlands 1965-1995. Journal of Marriage and Family, 64(1), 22539.

Logan TD (2010). Personal Characteristics, Sexual Behaviors, and Male Sex Work: A Quantitative Approach. American Sociological Review, 75(5): 679-704.

Martilla A (2008) Desiring the 'other': prostitution clients on a transnational red-light district in the border area of Finland, Estonia and Russia. Gender, Technology and Development, 12(1), 31-51.

McKeganey N and Barnard M (1996) Sex Work on the Streets: Prostitutes and their Clients, Buckingham: Open University Press.

McLeod E (1982) Working Women: Prostitution Now. London: Croom Helm.

Medved C E (2016). The new female breadwinner: discursively doing and undoing gender relations. Journal of Applied Communication Research, 44(3), 236-255.

Mercer C H, Tanton C, Prah P, Erens B, Sonnenberg P, Clifton S, Johnson, A. M. (2013) Changes in sexual attitudes and lifestyles in Britain through the life course and over time: findings from the National Surveys of Sexual Attitudes and Lifestyles (Natsal). The Lancet, 382(9907), 1781-1794.

Milrod, C. and Weitzer, R., (2012) The intimacy prism: Emotion management among the clients of escorts. Men and Masculinities, 15(5), 447-467.

Mooney-Somers J and Ussher J (2010) Sex as commodity: single and partnered men's subjectification as heterosexual men. Men and Masculinities, 12(3), 353-73.

Monto M (2000) 'Why men seek out prostitutes', in R. Weitzer (ed) Sex for Sale: Prostitution, Pornography and the Sex Industry, London: Routledge, pp. 67-84.

Neville, L (2018) Girls who like boys who like boys: Women and gay male pornography and erotica. Springer. 
Submission to Sexualities - Special Edition

O' Connell Davidson J and Sanchez-Taylor J (1999) Exploring the demand for sex tourism.

In Kempadoo K (Ed.), Sun, Sex, and Gold: Tourism and Sex Work in the Caribbean. Oxford:

Rowman \& Littlefield Publishers, pp. 37-54.

Office for National Statistics (2015) Divorces in England and Wales by age at and duration of marriage and cohort analyses: historical data. Retrieved from

https://www.ons.gov.uk/peoplepopulationandcommunity/birthsdeathsandmarriages/divorce/d atasets/divorcesinenglandandwalesageatmarriagedurationofmarriageandcohortanalyses

Office for National Statistics (2017) Births by parents' characteristics in England and Wales: 2015. Retrieved from

https://www.ons.gov.uk/peoplepopulationandcommunity/birthsdeathsandmarriages/livebirths /bulletins/birthsbyparentscharacteristicsinenglandandwales/2015

Offices, I. (Producer) (2018) What salary should you be earning at your age? Retrieved from https://www.instantoffices.com/blog/reports-and-research/average-uk-salary/

Oppermann M (1999) Sex tourism. Annals of Tourism Research, 26(2): 251-266.

Phillips J (2008) Female sex tourism in Barbados: postcolonial perspective. Brown Journal of World Affairs 14(2): 201-212.

Phipps, A (2014) The Politics of the Body, Cambridge: Polity Press.

Plummer K (2015) Cosmopolitan Sexualities, Cambridge: Polity Press.

Pickering H, Quigley M, Hayes RJ, Todd J \& Wilkins A (1993) Determinants of condoms use in 24,000 prostitute/client contacts in The Gambia. AIDS, 7(8): 1093-1098

Pilcher, K (2011) A ‘sexy space' for women? Heterosexual women's experiences of a male strip show venue. Leisure Studies, 30(2): 217-235.

Pilcher, K (2016) Erotic performance and spectatorship: New frontiers in erotic dance. Routledge. 
Submission to Sexualities - Special Edition

Pitts MK, Smith A, Grierson J, O'Brien M. and Misson S (2004) Who pays for sex and why? An analysis of social and motivational factors associated with male clients of sex workers', Archives of Sexual Behaviour 33(4): 353-358.

Prasad M (1999) The morality of market exchange: Love, money, and contractual justice. Sociological Perspectives, 42(2): 181-213.

Price, J., Patterson, R., Regnerus, M., \& Walley, J. (2016). How Much More XXX is Generation X Consuming? Evidence of Changing Attitudes and Behaviors Related to Pornography Since 1973. The Journal of Sex Research, 53(1), 12-20.

Pruitt D and LaFont S (1995) For love and money: Romance tourism in Jamaica. Annals of Tourism Research, 22(2): 422-440.

Pruitt MV and Krull AC (2010) Escort Advertisements and Male Patronage of Prostitutes, Deviant Behavior, 32 (1): 38-63.

Queen C and Comella L (2008) The necessary revolution: Sex-positive feminism in the postBarnard era. The Communication Review, 11(3), pp.274-291.

Rahman, M., \& Jackson, S. (2010). Gender \& Sexuality: Sociological Approaches. Cambridge: Polity Press.

Sanchez-Taylor J (2006) Female Sex Tourism: A Contradiction in Terms? Feminist Review, (83): 42-59. Available at: http://www.jstor.org/stable/3874382

Sánchez-Taylor J (2001) Dollars are a girl's best friend? Female tourists' sexual behaviour in the Caribbean. Sociology, 35(3): 749-764.

Sanders T (2008a) Paying for Pleasure: Men who buy sex. Cullompton, Willan Publishing. Sanders T (2008b) Male sexual scripts: intimacy, sexuality and pleasure in the purchase of commercial sex. Sociology, 42(3), 400-17. 
Submission to Sexualities - Special Edition

Sanders-McDonagh, E (2010) Situating the female gaze: understanding (sex) tourism practices in Thailand. In: New sociologies of sex work Hardy. K., Kingston, S. and Sanders, T. eds. Ashgate, pp. 109-122.

Sanders-McDonagh, E (2015) Porn by any other name: women's consumption of public sex performances in Amsterdam. Porn Studies, 2(4), 329-341.

Sanders-McDonagh, E (2016) Women and sex tourism landscapes. Routledge.

Scott S (1998) Changing attitudes to sexual morality: a cross-national comparison. Sociology, $32(4), 815-45$.

Vanwesenbeeck I, de Graf R., van Zessesn G, Straver CJ, and Visser JH (1993). Protection Styles of Prostitutes' Clients: Interventions, Behvaiour, and Considerations in Relation to AIDS. Journal of Sex Education and Therapy, 19(2): 79-92.

Weeks J (2009) The remaking of erotic and intimate life. Politica y Sociedad, 46(1), 13-25.

Weeks J (2007). The World We have Won: The Remaking of Erotic and Intimate Life. London: Routledge.

Weeks J (2003) Sexuality, $2^{\text {nd }}$ edition. London, Routledge.

Weitzer R (2009) ‘Sociology of sex work’ Annual Review of Sociology, 213-34.

Xantidis L and McCabe MP (2000). Personality characteristics of male clients of female commercial sex workers in Australia. Archives of Sexual Behaviour, 29(2): 165-176. 